\title{
The Book of Isaiah
}

In the second part of the issue, there are published three texts, which were presented at the international biblical conference on the Book of the prophet Isaiah entitled 'The Evangelical Prophet Isaiah Prophesied' (Prorok evangelický Isaiáš prorokoval) on December 7, 2018, at the Catholic Theological Faculty of Charles University in Prague. The conference report is included in this issue.

The prominent discovery of a scroll with a complete text of Isaiah in the mid-20th century in Qumran significantly contributed to the study and interpretation of this Old Testament book. In his study on Isa. 7:17, Libor Marek shows how the Qumran community read biblical texts. They were far from any conservative approach. Together with the careful attention to the text in its exact wording, they applied the prophetic word to their situation. In this case, they used the ambiguous functions of the text, i.e. the punishment and the promise of salvation, and reworked its statement by omitting conflicting elements and re-contextualizing it into the present circumstances of the community. This approach to the Scripture is demonstrated in two quotations of Isa. 7:17 in the Damascus Document (or: Cairo Document $=\mathrm{CD}$ ). In both cases, a negative interpretation of the Isaiah's statement is applied. The first passage in CD VII warns the present members of the community against the negative example of those who left the historical community. At the same time, however, the positive aspect of the prophecy that promises the faithful members of the community to escape to the northern country is also used (CD VII, 13). The second passage in CD XIII contains the legislation governing community life. The author of the Qumran text finds the common elements of his community with the text of Isaiah. Those who follow these instructions may have hope. On the contrary, those who reject them are expelled from the country and are deprived of any hope of change. This context confirms the negative aspect of Isaiah's statement.

The prophet Isaiah is one of the most frequently cited Old Testament books in the New Testament writings. New Testament researchers do not ignore this fact. Mireia Ryšková studies the reception and interpretation of Isaiah's quotations in Paul's greatest letter addressed to Rome. Paul selects quotes from all Isaiah's book; his preference for the Second Isaiah, as some believe, cannot be confirmed. The Judaism of Paul's time not only quoted Scriptures with literary accuracy but also made 
use of the dynamic power of God's Word. Biblical words are understood as divine 'inspiration'. This power of the Spirit works in the interpreter and through him God speaks to His contemporaries. For example, the trial of Isaiah's unfaithful Israel is applied by Paul to his Jewish contemporaries who have not received the gospel. At the same time, the Apostle shares Isaiah's eschatological vision of Israel's salvation, which is the hope for him that this people of God will eventually be saved. Finally, it is typical of Paul that he interprets the old prophecy christologically and demonstrates how their soteriological promise is fulfilled in Jesus and his Paschal mystery.

In addition to literal quotations and their resulting interpretation, socalled allusions of the Old Testament texts are also studied in the contemporary New Testament research. These illustrate how deeply the writers of the New Testament texts were rooted in their religious culture and biblical tradition. Július Pavelčík applies this methodological approach to the Letter of James demonstrating thereby that direct quotations from the Pentateuch and the wisdom literature do not exhaust the author's dealing with biblical texts. A careful comparative study of the Septuagint vocabulary, the close context of Isaiah's statements and their characteristic themes on the one hand, and the analysis of the text of the Epistle of James on the other indicates that prophetic literature, and especially Isaiah's book, should be seen as an indispensable hermeneutic framework for interpreting this and perhaps even other Catholic epistles.

The three studies are only a tiny fraction of the vast research of the book of the prophet, who is in the Christian environment sometimes called the 'Evangelist of the Old Testament'. The results of this research have demonstrated that the message of the prophet Isaiah is not present among us only in his preserved written text, but he lived throughout many past generations of interpreters and - as we believe - he still does.

Jaroslav Brož

doi: $10.14712 / 23363398.2020 .2$ 